\title{
Burn-induced distant organ injury in rats and the effect of minocycline
}

\author{
Sıçanlarda yanık ile uyarılan uzak organ hasarı ve minosiklinin etkisi
}

\author{
Elif BAHADIR, Murat SANCAR, Gazi Giray TARHAN, Emre KOÇAK, Zeynep BUDANCAMANAK, Seda \\ KARAASLAN, Elif KERVANCIOĞLU DEMIRCI, Meral YÜKSEL, Feriha ERCAN, İnci ALİCAN
}

\begin{abstract}
Objectives: This study aimed to examine the anti-inflammatory potential of orally-administered minocycline, a semi-synthetic second-generation tetracycline, on burn-induced liver and kidney damage in rats.

Materials and Methods: Female Sprague-Dawley rats (250$300 \mathrm{~g} ; \mathrm{n}=7-8 /$ group) were used. Burn and sham groups were exposed to $90{ }^{\circ} \mathrm{C}$ and $25{ }^{\circ} \mathrm{C}$ water bath for $10 \mathrm{~s}$, respectively. Minocycline (20 $\mathrm{mg} / \mathrm{kg}$; twice daily; orogastrically) was administered for $24 \mathrm{~h}$ post-burn. After decapitation, trunk blood was collected for biochemical assays. Liver and kidneys were excised for histopathological evaluation and malondialdehyde (MDA), glutathione and chemiluminescence (CL) assays.

Results: Minocycline treatment did not exert a significant effect on serum alanine aminotransferase, aspartate aminotransferase, blood urea nitrogen, and creatinine levels of the burn group. Increased serum total oxidant status of the burn group was reversed $(P<0.001)$ and liver microscopic lesion score showed a slight reduction $(P<0.01)$ by minocycline. Minocycline did not cause a significant effect on increased tissue MDA and glutathione levels of the burn group but reversed the elevated luminol CL levels ( $P<0.001$, for liver and $P<0.01$, for kidney, respectively).

Conclusion: Minocycline treatment to rats for $24 \mathrm{~h}$ post-burn was found to be effective to reduce oxidant production in the liver and kidney; however, it showed slight protection on these tissues against oxidant damage.
\end{abstract}

Keywords: Burn, Kidney, Liver, Minocycline, Rat

İnci Alican (两)

Department of Physiology, School of Medicine, Marmara University, Maltepe, Istanbul, Turkey

e-mail:incialican@yahoo.com

Elif Bahadır, Murat Sancar, Gazi Giray Tarhan, Emre Koçak, Zeynep Budancamanak, Seda Karaaslan

3rd year medical student, School of Medicine, Marmara University, Maltepe, Istanbul, Turkey

Elif Kervancioğlu Demirci, Feriha Ercan

Department of Histology and Embryology, School of Medicine, Marmara University, Maltepe, Istanbul, Turkey

Meral Yüksel

Vocational School of Health Services, Marmara University, Haydarpaşa, Istanbul, Turkey

Submitted / Gönderilme: 12.05.2017

Accepted/Kabul: 21.06 .2017
Öz

Amaç: Bu çalışma, oral uygulanan minosiklinin -yarı sentetik ikinci kuşak tetrasiklin- sıçanlarda yanık ile uyarılan karaciğer ve böbrek hasarı üzerine anti-inflamatuvar potansiyelini incelemeyi amaçlamıştır.

Gereç ve Yöntem: Çalışmada dişi Sprague-Dawley sıçanlar (250-300 g; n=7-8/grup) kullanıldı. Yanık ve taklit grupları, siras1 ile $90{ }^{\circ} \mathrm{C}$ ve $25^{\circ} \mathrm{C}$ 'lik su banyosunda 10 saniye tutuldu. Minosiklin (20 mg/kg; günde iki kez; orogastrik yolla) yanık sonrası 24 saat süreyle uygulandı. Dekapitasyon sonrası, biyokimyasal ölçümler için gövde kanı toplandı. Histopatolojik inceleme ve malondialdehit (MDA), glutatyon ve kemiluminisans (CL) ölçümleri için karaciğer ve böbrekler çıkarıldı.

Bulgular: Minosiklin tedavisi yanık grubuna ait serum alanin aminotransferaz, aspartat aminotransferaz, kan üre azotu ve kreatinin düzeylerine anlamlı bir etki göstermedi. Yanık grubunda artmış serum toplam oksidan durum $(P<0.001)$ minosiklin ile geri döndürüldü $(P<0.001)$ ve karaciğer mikroskopik hasar skoru hafif azalma $(P<0.01)$ gösterdi. Minosiklin yanık grubunda artmış doku MDA ve glutatyon düzeyleri üzerine anlamlı etki göstermedi ancak artmış luminol CL düzeylerini geri döndürdü $(P<0.001$, karaciğer ve $P<0.01$, böbrek).

Sonuç: Sıçanlara yanık sonrası 24 saat minosiklin tedavisi karaciğer ve böbrekte oksidan oluşumunu azaltmada etkin bulunmuştur; ancak bu dokuları oksidan hasara karşı hafif derecede koruyucu bir etki göstermiştir.

Anahtar kelimeler: Böbrek, Karaciğer, Minosiklin, Sıçan, Yanık

\section{Introduction}

Severe burn injury causes an inflammatory response and serious metabolic disturbances such as cardiac dysfunction, acute respiratory distress syndrome, acute renal failure, and sepsis due to increased intestinal permeability. Multi-organ failure following a burn insult continues to be a serious problem in the clinical medicine. 
Local burn insult produces damage in remote organs such as lung, liver, and kidneys within hours of injury. Thus, organ protection is essential for patients with severe burn/scald injuries. Although, the pathophysiological mechanism of injury in visceral organs distant to local burn is not clear, animal models and clinical trials have demonstrated that reactive oxygen species (ROS) play a critical role. Endotoxin and other bacterial-end products which become evident in the circulation as a result of burn wound colonization may activate macrophages and neutrophils. This leads to the release of oxidants, arachidonic acid metabolites, proteases, etc, which cause further injury in distant organs [1-6].

Minocycline is a semi-synthetic second-generation tetracycline with anti-apoptotic, immunosuppressive and anti-inflammatory actions in various pathological states including acne vulgaris, periodontitis, rheumatoid arthritis, asthma, scleroderma, Parkinson's disease and Huntington's disease [7-10]. Underlying mechanisms of minocycline's anti-inflammatory actions which are independent from its main clinical use as an antimicrobial, include the inhibition of ROS, and cytokine production, interference with protein synthesis and modulation of matrix metalloproteinase activity [11,12]. Previous studies have shown that minocycline inhibits phospholipase A2, and neutrophil migration and adhesion [13-15]. Additionally, minocycline directly scavenges ROS in several cell-free mixed-radical assays with a potency comparable to vitamin E [16]. Its oxidant-scavenging ability is attributed to its multiple-substituted phenol ring which generates a relatively stable and unreactive phenolic radical when binds to a free radical.

Chang et al. [17] established a unilateral partialthickness second-degree burn-injury model in rats and examined the effect of minocycline on the level of pain. The results of the study demonstrated that daily treatment with minocycline, administered at the time of burn injury and for 7 days thereafter, attenuated ipsilateral and contralateral allodynia and significant suppression of evoked hyperexcitability of dorsal-horn neurons. However, the effect of minocycline on distant organ damage following a burn insult has not been investigated. Therefore, in the light of these previous observations, this study was undertaken to examine the effectiveness of minocycline in terms of its anti-inflammatory and antioxidant actions on the extent of damage the liver and kidney $24 \mathrm{~h}$ after a burn insult in rats.

\section{Materials and Methods}

\section{Animals}

Female Sprague-Dawley rats (250-300 g; $\mathrm{n}=7-8$ per group) were kept in a room at a constant temperature

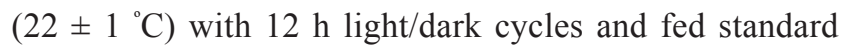
pellet chow and water ad libitum. The study protocol was approved by Marmara University Ethics Committee for the Care and Use of Experimental Animals. All experimental procedures were conducted in accordance with the Guide to the Care and Use of Laboratory Animals.

\section{Experimental protocol}

Under ether anesthesia, the dorsum of the rats were shaved and exposed to $90{ }^{\circ} \mathrm{C}$ water bath for $10 \mathrm{~s}$ (Burn group). This protocol has been shown to result in a partial-thickness second-degree skin burn involving 30\% of the total body surface area [18]. The animals in sham group were dipped in a $25{ }^{\circ} \mathrm{C}$ water bath for $10 \mathrm{~s}$. Minocycline (Carbosynth Ltd, Berkshire, UK) was dissolved in distilled water and administered orogastrically at a dose of $20 \mathrm{mg} / \mathrm{kg}(1 \mathrm{~mL})$ twice daily $30 \mathrm{~min}$ after the burn insult. The treatment was continued for $24 \mathrm{~h}$. The dose of minocycline was chosen according to literature data $[19,20]$. Sham group received the vehicle (distilled water; $1 \mathrm{~mL}$ ) orogastrically for $24 \mathrm{~h}$. Burn groups were resuscitated with lactated Ringer's solution (20 $\mathrm{ml} / \mathrm{kg}$, subcutaneously) immediately after the burn insult.

All animals were decapitated at $24 \mathrm{~h}$ after the burn insult. Blood samples were collected, and the liver and kidneys were harvested. Blood samples were centrifuged at 3,000 g for $15 \mathrm{~min}$ and serums were stored at $-80{ }^{\circ} \mathrm{C}$ for the assessment of alanine aminotransferase (ALT), aspartate aminotransferase (AST), blood urea nitrogen (BUN), and creatinine levels and for total oxidant status (TOS) and antioxidant capacity assays (TAC). Liver and kidney samples were taken for histological evaluation of the lesions by light microscopy or stored at $-80{ }^{\circ} \mathrm{C}$ for subsequent measurement of malondialdehyde (MDA) level (a lipid peroxidation marker) and endogenous antioxidant glutathione content. Formation of ROS in tissue samples was monitored using the chemiluminescence (CL) method.

\section{Measurement of serum ALT, AST, BUN and creatinine levels}

Serum ALT, AST, BUN and creatinine levels were measured by means of standard spectrophotometric methods using 
an autoanalyzer (Cobas 8000 Modular Analytics, Roche Diagnostics, Germany).

\section{Serum TOS and TAC assays}

Serum TOS and TAC levels were measured using the colorimetric methods using a commercial kit (Rel Assay Diagnostics, Gaziantep, Turkey) via an autoanalyzer (PG Instruments Ltd, Leicestershire, UK) as described previously [21,22]. TOC results are expressed as mmol $\mathrm{H}_{2} \mathrm{O}_{2}$. Equivalence per liter of serum and TAC results are expressed as mmol Trolox Equivalence per liter of serum.

\section{Histological evaluation}

For light microscopic investigation, liver and kidney samples were placed in $10 \%$ formaldehyde, dehydrated in ascending alcohol series (70\%, 90\%, 96\% and 100\%), and embedded in paraffin. For each animal, four randomly taken tissue sections $(5 \mu \mathrm{m})$ were stained with hematoxylin and eosin (H\&E) and visualized with a microscope (Olympus BX51, Tokyo, Japan). Five to nine tissue sections from each animal were randomly chosen. From each section, five areas were randomly selected for histopathological examination. Semiquantitative scoring (maximum score=4) was performed using the criteria as demonstrated in Table I. The histopathologic score was determined by an experienced histologist (F.E) who was unaware of the treatment groups.

\section{Measurement of MDA and glutathione levels}

Liver and kidney samples were homogenized in 10 volumes of ice-cold $10 \%$ trichloracetic acid and centrifuged at $3,000 \mathrm{~g}$ for $15 \mathrm{~min}$ at $4{ }^{\circ} \mathrm{C}$. Supernatant was removed and recentrifuged at $10,000 \mathrm{~g}$ at $4{ }^{\circ} \mathrm{C}$ for $8 \mathrm{~min}$. Glutathione was determined by a spectrophotometric method which is a modification of Ellman procedure [23]. Lipid peroxide levels are expressed in terms of MDA equivalents as nmol MDA per $g$ tissue [24].

\section{Chemiluminescence assay}

Luminescence of the liver and kidney homogenates was recorded at room temperature using Mini Lumat LB 9506 luminometer (EG\&G Berthold, Germany) in the presence of luminol or lucigenin $0.2 \mathrm{mM}$ each. All counts were obtained at $15 \mathrm{~s}$ intervals for $5 \mathrm{~min}$ and the results were expressed as area under the curve (AUC) of relative light unit (rlu) for $5 \mathrm{~min}$ per $\mathrm{mg}$ of tissue. The calculation was based on the integration of the curve by the trapezoidal rule (a linear approximation) [25].

\section{Statistical analysis}

All data are expressed as means \pm S.E.M. The histological data were compared using Mann-Whitney U non-parametric test. Other parameters were compared using two-way analysis of variance (ANOVA) followed by Tukey-Kramer multiple comparison tests. Values of $P<0.05$ were regarded as significant. Calculations were done using Instat statistical analysis package (GraphPad Software, San Diego, CA, USA).

\section{Results}

\section{Serum ALT, AST, BUN and creatinine levels}

As demonstrated in Table II, serum ALT and AST levels

- biomarkers of hepatocellular injury-showed marked increases in burn group compared to sham group $(P<0.001)$.

Table I. Criteria used for microscopic scoring of burn-induced damage in liver and kidney samples.

\begin{tabular}{lcl}
\hline Tissue & Score & \multicolumn{1}{c}{ Appearance } \\
\hline Liver & 0 & Normal \\
& 1 & Expansion and vacuolization of hepatocytes \\
& 2 & Vascular congestion and expansion of sinusoids \\
& 3 & Mild increase in number of Kupffer cells \\
& 4 & Severe increase in number of Kupffer cells \\
\hline Kidney & 0 & Normal \\
& 1 & Degeneration of proximal tubuli \\
& 2 & Vascular congestion \\
& 3 & Mild glomerular congestion and degeneration \\
& 4 & Severe degeneration of glomerular structure and expansion of Bowman's space \\
\hline
\end{tabular}


Table II. Serum alanine aminotransferase (ALT), aspartate aminotransferase (AST), blood urea nitrogen (BUN), and creatinine levels of the experimental groups.

\begin{tabular}{lcccc}
\hline & $\begin{array}{c}\text { ALT } \\
(\mathbf{U} / \mathbf{L})\end{array}$ & $\begin{array}{c}\text { AST } \\
(\mathbf{U} / \mathbf{L})\end{array}$ & $\begin{array}{c}\text { BUN } \\
(\mathbf{m g} / \mathbf{d L})\end{array}$ & $\begin{array}{c}\text { Creatinine } \\
(\mathbf{m g} / \mathbf{d L})\end{array}$ \\
\hline Sham & $51.50 \pm 3.27$ & $167.40 \pm 15.38$ & $12.94 \pm 0.63$ & $0.25 \pm 0.001$ \\
Burn & $124.00 \pm 4.42^{* * *}$ & $616.00 \pm 38.29^{* * *}$ & $25.08 \pm 3.26^{* *}$ & $0.30 \pm 0.02^{*}$ \\
Burn+Min & $127.80 \pm 6.61^{* * *}$ & $527.30 \pm 49.58^{* * *}$ & $17.93 \pm 2.04^{*}$ & $0.31 \pm 0.02^{*}$ \\
\hline
\end{tabular}

Min: minocycline

Data are means \pm SEM of 8 rats for each group. $* P<0.05$, $* * P<0.01$, and ${ }^{* * *} P<0.001$, compared to sham group.

In minocycline-treated burn group, the serum ALT and AST levels did not show statistically significant differences when compared with those of the untreated burn group. Burn insult also caused elevations in serum BUN and creatinine levels indicating kidney dysfunction $(P<0.01$, for BUN and $P<0.05$, for creatinine). Similarly, minocycline treatment had no significant effect on these parameters (Table II).

\section{Serum TOS and TAC assays}

As shown in Table III, TOS level of the burn group was significantly increased relative to that of the sham group $(P<0.001)$. Minocycline treatment to burn animals was associated with decreased TOS levels in comparison to untreated burn group $(P<0.01)$. Although, the sham and burn groups did not differ in terms of TAC levels, minocycline treatment increased the TAC levels of the burn animals in comparison to sham group $(P<0.05)$.

\section{Histological evaluation}

Liver samples of the burn group revealed sinusoidal congestion and dilation, inflammatory cell infiltration, increased number of activated Kupffer cells and perinuclear vacuolization and edema of the hepatocytes (Figure 1). The extent of sinusoidal dilation and congestion and the number of degenerated hepatocytes seemed to decrease in minocycline-treated burn group. The histopathological changes observed in liver samples were in the same line with the microscopic lesion scores of the experimental groups. That is, the microscopic lesion score of the burn group $(3.44 \pm 0.22 ; P<0.001)$ showed a slight reduction by minocycline treatment $(2.44 \pm 0.17$; $P<0.01$ ) (Figure 2).

In burn group, the kidney samples revealed glomerular and vascular congestion, expansion of Bowman's space, degeneration and desquamation of tubular cells and expansion of the tubuli (Figure 3). Although minocycline decreased glomerular congestion it did not modulate the severity of the damage in terms of other microsocopic scoring criteria. The kidney microscopic lesion scores of the burn and minocycline-treated burn groups were $3.50 \pm 0.19$ and $2.81 \pm 0.26$, respectively (Figure 2).

\section{Tissue MDA and Glutathione levels}

The burn group presented increased MDA and glutathione levels in both liver and kidney samples when compared with the sham group. Burn-induced changes of these parameters were preserved by minocycline treatment (Table IV).

Table III. Serum total oxidant status (TOS) and total antioxidant capacity (TAC) levels of the experimental groups.

\begin{tabular}{lcc}
\hline & TOS & TAC \\
& $(\mathbf{m m o l}$ H2O2 Equiv/L) & $\begin{array}{c}\text { (mmol Trolox Equiv/L) } \\
\text { Sham }\end{array}$ \\
Burn & $7.14 \pm 1.33$ & $4.13 \pm 0.27$ \\
Burn+Min & $27.43 \pm 4.00^{* * *}$ & $4.61 \pm 0.13$ \\
\hline
\end{tabular}

Min, minocycline

Data are means \pm SEM of 8 rats for each group. ${ }^{*} P<0.05$, and ${ }^{* * *} P<0.001$, compared to sham group. ${ }^{++} P<0.01$, compared to burn group. 

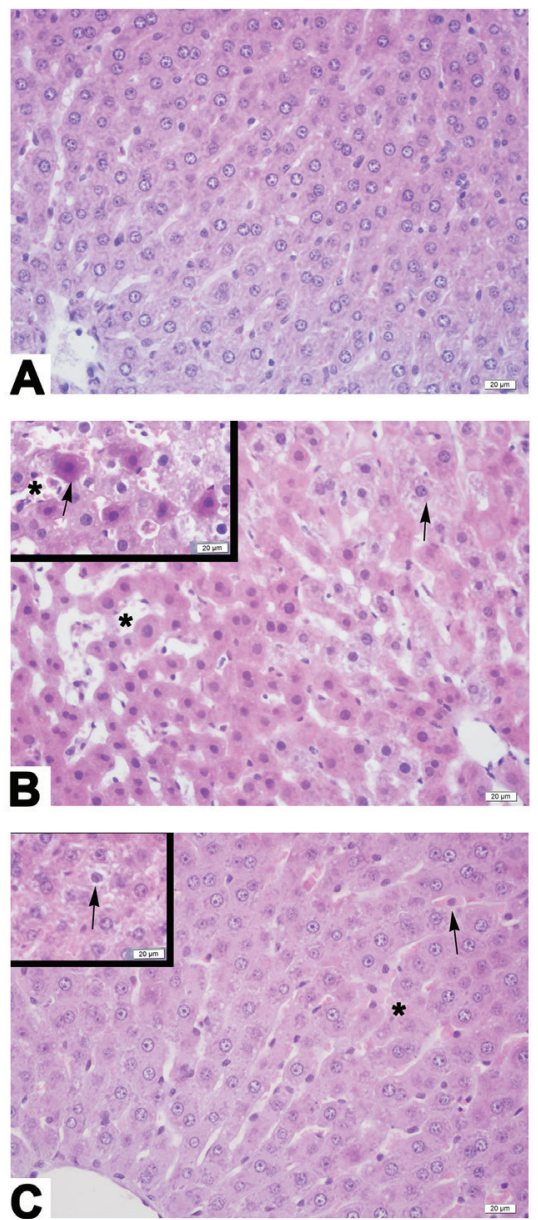

Figure 1. Micrographs illustrating the histological appearances of liver samples from experimental groups. Sham group (A) with normal liver parenchyma. Burn group (B), with sinusoidal expansion and congestion $(*)$, degeneration of hepatocytes with vacuolization (arrow) or eosinophilic cytoplasm (arrow, inset). Burn+minocycline group (C) with less sinusoidal expansion and congestion $(*)$ and less number of degenerated hepatocytes (arrow). H\&E staining, original magnifications 200x, inset 400x.

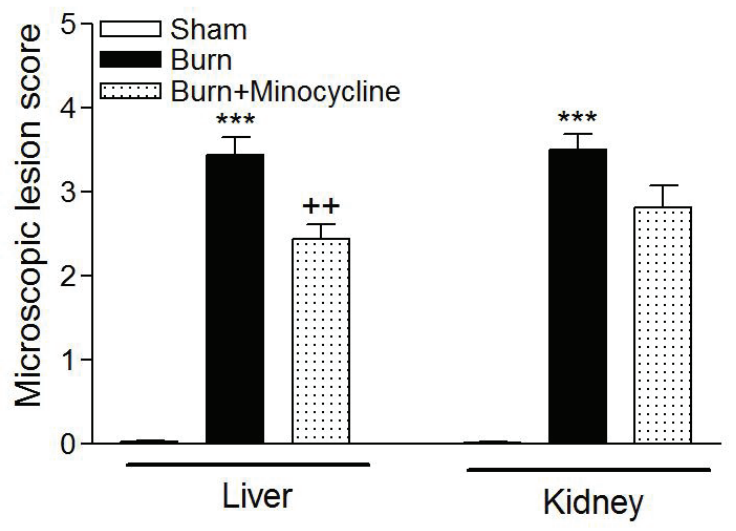

Figure 2. Microscopic lesion score in liver and kidney samples of the experimental groups. $* * * P<0.001$, compared to sham group. ${ }^{++} P<0.01$, compared to burn group.
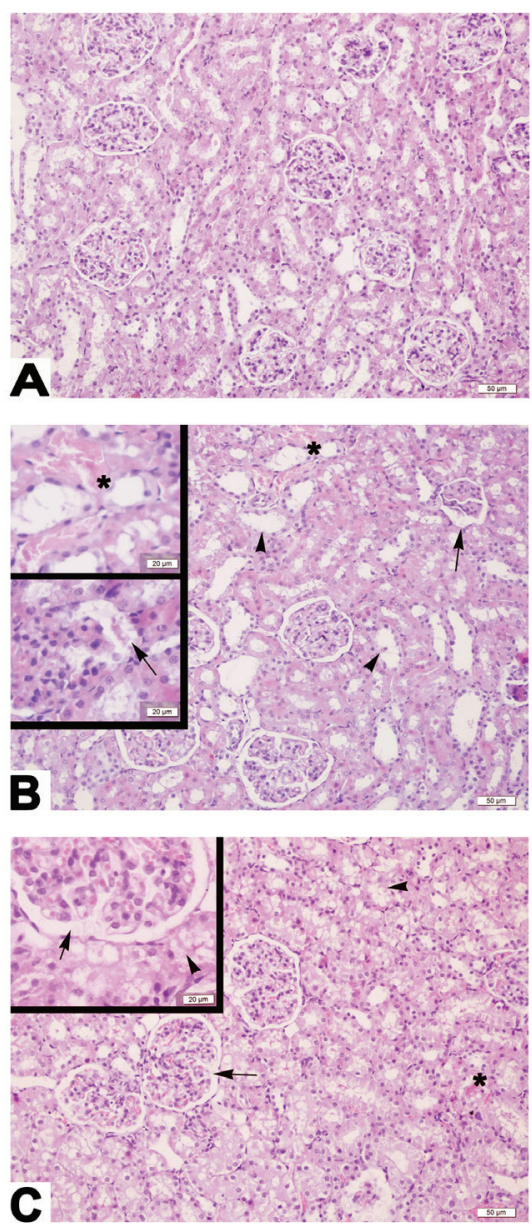

Figure 3. Micrographs illustrating the histological appearances of kidney samples from experimental groups. Sham group (A) with normal renal parenchyma. Burn group (B), with glomerular congestion, expansion of Bowman's space and cell debris (arrow), vascular congestion $(*)$, and expansion of tubuli and tubular degeneration (arrow head). Burn+minocycline group (C) with less glomerular congestion, Bowman's space with normal morphology (arrow), expansion and degeneration in less number of tubuli (arrow head). H\&E staining, original magnifications 200x, inset $400 x$.

\section{Chemiluminescence values}

Both liver and kidney luminol-enhanced CL levels showed significant increases in the burn group compared to sham $(P<0.01)$. The elevations of luminol-enhanced CL levels in both tissues were reversed by minocycline $(P<0.001$, for liver and $P<0.01$, for kidney). No statistically significant changes were observed among the experimental groups in terms of lucigenin-enhanced CL levels (Table V). 
Table IV. Liver and kidney malondialdehyde (MDA) and glutathione levels of the experimental groups.

\begin{tabular}{lcccc}
\hline & $\begin{array}{c}\text { MDA } \\
(\mathbf{n m o l} / \mathbf{g})\end{array}$ & $\begin{array}{c}\text { Liver } \\
\text { Glutathione } \\
(\boldsymbol{\mu m o l} / \mathbf{g})\end{array}$ & $\begin{array}{c}\text { MDA } \\
(\mathbf{n m o l} / \mathbf{g})\end{array}$ & $\begin{array}{c}\text { Kidney } \\
(\boldsymbol{\mu m o l} / \mathbf{g})\end{array}$ \\
\hline Sham & $9.63 \pm 1.01$ & $3.68 \pm 0.14$ & $13.89 \pm 0.68$ & $1.39 \pm 0.16$ \\
Burn & $25.42 \pm 1.44^{* * *}$ & $4.42 \pm 0.21^{*}$ & $18.82 \pm 0.78^{* * *}$ & $2.92 \pm 0.26^{* * *}$ \\
Burn+Min & $22.18 \pm 3.17^{*}$ & $4.49 \pm 0.12^{* * *}$ & $26.02 \pm 1.92^{* * *+}$ & $3.59 \pm 0.18^{* * *}$ \\
\hline
\end{tabular}

Min: minocycline

Data are means \pm SEM of 8 rats for each group. ${ }^{*} P<0.05$, ${ }^{* * *} P<0.001$, compared to sham group. ${ }^{++} P<0.01$, compared to burn group.

Table V. Liver and kidney luminol- and lucigenin-enhanced chemiluminescence (CL) levels of the experimental groups.

\begin{tabular}{|c|c|c|c|c|}
\hline & \multicolumn{2}{|c|}{ Liver } & \multicolumn{2}{|c|}{ Kidney } \\
\hline & $\begin{array}{c}\text { Luminol- } \\
\text { enhanced CL } \\
\text { (rlu/mg) }\end{array}$ & $\begin{array}{c}\text { Lucigenin- } \\
\text { enhanced CL } \\
\text { (rlu/mg) }\end{array}$ & $\begin{array}{c}\text { Luminol- } \\
\text { enhanced CL } \\
\text { (rlu/mg) }\end{array}$ & $\begin{array}{c}\text { Lucigenin- } \\
\text { enhanced CL } \\
\text { (rlu/mg) }\end{array}$ \\
\hline Sham & $1.94 \pm 0.19$ & $2.59 \pm 0.15$ & $1.55 \pm 1.13$ & $1.75 \pm 0.08$ \\
\hline Burn & $3.51 \pm 0.36^{* *}$ & $3.05 \pm 0.25$ & $2.78 \pm 0.35^{* *}$ & $1.87 \pm 0.17$ \\
\hline Burn+Min & $1.35 \pm 0.16^{+++}$ & $2.79 \pm 0.44$ & $1.73 \pm 0.25^{++}$ & $1.93 \pm 0.11$ \\
\hline
\end{tabular}

Min: minocycline

Data are means \pm SEM of 8 rats for each group. ${ }^{*}{ }^{*} P<0.01$, compared to sham group. ${ }^{++} P<0.01$, and ${ }^{+++} P<0.001$, compared to burn group.

\section{Discussion}

Severe burn may lead to multiple organ dysfunction and death as a result of disruption of the body's homeostatic balance. This study examined the histopathological and biochemical changes that occur in liver and kidneys of rats $24 \mathrm{~h}$ after induction of partial-thickness second-degree skin burn and evaluated the effectiveness of minocycline to limit the extent of tissue injury via its putative anti-inflammatory and anti-oxidant actions.

The relationship between local inflammation and subsequent systemic inflammatory response is unclear. In addition to local inflammation, severe skin burn induces the systemic inflammatory response syndrome (SIRS) [26]. The mechanisms that are responsible for distant organ damage after local injury, include the systemic liberation of proinflammatory mediators, neutrophil attraction, and activation of the sympathetic inflammatory signaling $[27,28]$. It is known that gut barrier function is compromised following thermal injury and that endotoxins and other bacterial by-products as a result of burn wound colonization contribute to damage in distant organs. Endotoxin translocates across the gastrointestinal tract barrier within $1 \mathrm{~h}$ of thermal injury and plasma endotoxin concentration reaches a peak at $12 \mathrm{~h}$ and 4 days postburn [29,30]. Endotoxins are potent activators of the macrophages and neutrophils. Activation of these inflammatory cells leads to the release of oxidants, arachidonic acid metabolites and proteases, all of which cause further local and systemic inflammation following burn [31]. In our study, we observed severe tissue damage in both liver and kidney samples at microscopic level and increased blood ALT, AST, BUN and creatinine levels in the burn group compared to sham implying hepatic and renal dysfunction. There were increased lipid peroxidation (as shown by MDA assay) and antioxidant glutathione levels in the liver and kidney samples of burned animals when compared with those of the sham group. We also observed marked elevations in luminol-enhanced CL values in the liver and kidneys and increase in TOS values in the serum of burned animals. All these results suggest that partial-thickness second-degree skin burn rat model causes oxidative stress in liver and kidney at $24 \mathrm{~h}$ post-burn.

Tetracycline antibiotics were the first major class of 'broad-spectrum antibiotics' which have been used since 1940s against a wide range of both Gram-positive and 
Gram-negative pathogens, mycoplasmas, intracellular chlamydia, rickettsia and protozoan parasites. The second generation of semisynthetic tetracyclines, minocycline and doxycycline, with improved antimicrobial potency, were introduced during the 1960s. Tetracyclines, in addition to their antimicrobial properties, exhibit inhibitory activity toward the inflammatory cascade and mediators of tissue damage [32]. As reported, minocycline also possesses potent anti-apoptotic properties. It inhibits caspase 1 and 3 expressions and directly blocks cytochrome c release from mitochondria [10,33]. Recent studies have shown that anti-inflammatory and immunomodulatory actions of minocycline are not related to its antimicrobial property [34]. Minocycline suppresses the secretion interleukin (IL)-1beta, IL-8 and tumor necrosis factor (TNF)-alpha, in macrophages stimulated by lipopolysaccharides (LPS) [35]. An in vitro study by Leite et al. [20] tested the antioxidant activity of minocycline by the 2,2-diphenyl-1-picrylhydrazyl (DPPH) assay and found that minocycline has an antioxidant activity which is more potent than alpha-tocopherol. In the same study, the anti-inflammatory properties of doxycycline and minocycline were also compared in in vivo and in vitro settings. In general, the anti-inflammatory activity of doxycycline was found to be higher as compared to that of minocycline, although the radical scavanging activity of minocycline was of a magnitude 10 times higher [20]. A very recent in vitro study by Parenti et al. [36] demonstrated that minocycline significantly inhibited oxidative burst of human polymorphonuclear (PMN) cells stimulated with N-formylmethionyl-leucyl-phenylalanine (FMLP) in a concentration-dependent manner and impaired PMN transendothelial migration. Data from in vitro rat brain homogenate lipid peroxidation and DPPH assays showed that minocycline had an $\mathrm{IC}_{50}$ of 3-40 $\mathrm{mM}$ and was 9-250 times more potent as a scavanger than doxycycline [37]. ROS scavenging ability of minocycline is likely to be attributed to its unique structure, with diethylamino group on the phenolic carbon that provides steric hindrance [37]. Moreover, minocycline and to a lesser extent doxycycline inhibits phospholipase A2, neutrophil migration and adhesion, and lymphocyte proliferation [38-40]. Overall, it is believed that the anti-inflammatory action of minocycline involves the inhibition of mediators of the inflammatory process, including interleukins, prostaglandins, inducible nitric oxide synthase (iNOS), and an antioxidant activity.

ROS can cause tissue damage if the rate of their production exceeds the capacity of the endogenous antioxidant enzymes. Increased oxidative stress and impairment of antioxidant defenses by the deleterious effect of ROS contribute to the pathogenesis of the inflammatory conditions. CL measures light production as a byproduct of oxidative reactions and is a commonly used technique to estimate ROS generation in various tissues. Luminol and lucigenin CL probes have different selectivity towards radicals. Luminol quantifies hydrogen peroxide, hydroxyl radical, hypochlorite, peroxynitrite, and lipid peroxyl radicals whereas lucigenin is selective for superoxide radical [41]. In our study, we observed elevated luminol CL levels in liver and kidney samples of burn animals indicating the increased generation of hydrogen peroxide, hydroxyl radical, hypochlorite, peroxynitrite, and lipid peroxyl radicals in these tissues post-burn. In our study, minocycline at a daily dose of $40 \mathrm{mg} / \mathrm{kg}$ (20 mg/kg, twice daily) did not exert a statistically significant effect on the levels of lipid peroxidation and glutathione in liver and kidney samples of burn animals. However, there were marked reductions in luminol-enhanced CL levels in both tissues and the total oxidant status (TOS) in blood by minocycline treatment. Thus, these findings may suggest that minocycline is effective to reduce the level of ROS production in liver and kidney following burn. Another finding of the study was that minocycline did not attanuate the increased serum levels of liver enzyme activities and BUN and creatinine as indicators of cellular dysfunction. Similarly, the extent of liver and kidney injury at microscopic level in burn group showed slight preservation by minocycline. Thus, although minocycline treatment to burn animals suppresses oxidant production in liver and kidney it is not effective to protect these tissues against damage. To reveal minocycline's effectiveness on the extent of burn-induced tissue damage, a burn protocol possibly with prolonged minocycline treatment is warranted.

In conclusion, the administration of minocycline for $24 \mathrm{~h}$ beginning at the time of burn injury showed slight protection on liver and kidney against oxidant stress and damage.

\section{Conflict of interest}

None declared. 


\section{References}

1. Parihar A, Parihar MS, Milner S, Bhat S. Oxidative stress and anti-oxidative mobilization in burn injury. Burns 2008;34:617. doi: 10.1016/j.burns.2007.04.009

2. Magnotti LJ, Xu DZ, Lu Q, Deitch EA. Gut-derived mesenteric lymph: a link between burn and lung injury. Arch Surg 1999;134:1333-41.

3. Moore FA. The role of the gastrointestinal tract in postinjury multiple organ failure. Am J Surg 1999;178:449-53.

4. Sabeh F, Baxter CR, Norton SJ. Skin burn injury and oxidative stress in liver and lung tissues of rabbit models. Eur J Clin Chem Clin Biochem 1995;33:323-8.

5. Youn YK, Suh GJ, Jung SE, Oh SK, Demling R. Recombinant human growth hormone decreases lung and liver tissue lipid peroxidation and increases antioxidant activity after thermal injury in rats. J Burn Care Rehabil 1998;19:542-8.

6. Youn Y-K, LaLonde C, Demling R. The role of mediators in the response to thermal injury. World J Surg 1992;25:249-65.

7. Thomas M, Le WD. Minocycline: neuroprotective mechanisms in Parkinson's disease. Curr Pharm Des 2004;10:679-86.

8. Koistinaho M, Malm TM, Kettunen MI, Goldsteins G, Starckx S, Kauppinen RA, et al. Minocycline protects against permanent cerebral ischemia in wild type but not in matrix metalloprotease-9-deficient mice. J Cereb Blood Flow Metab 2005;25:460-7. doi: 10.1038/sj.jcbfm.9600040

9. Lee SM, Yune TY, Kim SJ, Park DW, Lee YK, Kim $\mathrm{YC}$, et al. Minocycline reduces cell death and improves functional recovery after traumatic spinal cord injury in the rat. J Neurotrauma 2003;20:1017-27. doi: 10.1089/089771503770195867

10. Chen M, Ona VO, Li M, Ferrante RJ, Fink KB, Zhu S, et al. Minocycline inhibits caspase- 1 and caspase- 3 expression and delays mortality in a transgenic mouse model of Huntington disease. Nat Med 2000;6:797-801. doi: 10.1038/77528

11. Padi SS, Kulkarni SK. Minocycline prevents the development of neuropathic pain, but not acute pain: possible antiinflammatory and antioxidant mechanisms. Eur J Pharmacol 2008;601:79-87. doi: 10.1016/j.ejphar.2008.10.018

12. Singh LP, Mishra A, Saha D, Swarnakar S. Doxycycline blocks gastric ulcer by regulating matrix metalloproteinase-2 activity and oxidative stress. World J Gastroenterol 2011;17:3310-21. doi: 10.3748/wjg.v17.i28.3310

13. Pruzanski W, Greenwald RA, Street IO, La-leberte F, Stefanski E, Vadas P. Inhibition of enzymatic activity of phospholipase A2 by minocycline and doxycycline. Biochem Pharmacol 1992;44:1165-70.

14. Esterly NB, Koransky JS, Furey NL, Trevisan M. Neutrophil chemotaxis in patients with acne receiving oral tetracycline therapy. Arch Dermatol 1984;120:1308-13.

15. Gabler WL, Tsukuda N. The influence of divalent cations and doxycycline on iodoacetamide-inhibitable leukocyte adherence. Res Commun Chem Pathol Pharmacol 1991;74:131-40.

16. Kraus RL, Pasieczny R, Lariosa-Willingham K, Turner MS, Jiang A, Trauger JW. Antioxidant properties of minocycline: neuroprotection in an oxidative stress assay and direct radical-scavenging activity. J Neurochem 2005;94:819-27. doi.10.1111/j.1471-4159.2005.03219.x

17. Chang Y-W, Waxman SG. Minocycline attenuates mechanical allodynia and central sensitization following peripheral second-degree burn injury. J Pain 2010;11:114654. doi. 10.1016/j.jpain.2010.02.010

18. Oktar BK, Yüksel M, Alican İ. The effect of alpha-melanocyte stimulating hormone on burn-induced oxidant production by rat peritoneal neutrophils. MMJ 2003;16:7-11.

19. Li Y, li T, Qi H, Yuan F. Minocycline protects against hepatic ischemia/reperfusion injury in a rat model. Biomed Rep 2015;3:19-24. doi: 10.3892/br.2014.381

20. Leite LM, Carvalho AG, Ferreira PL, Pessoa IX, Gonçalves DO, Lopes Ade A, et al. Anti-inflammatory properties of doxycycline and minocycline in experimental models: an in vivo and in vitro comparative study. Inflammopharmacol 2011;19:99-110. doi: 10.1007/s10787-011-0077-5

21. Erel O. A novel automated method to measure total antioxidant response against potent free radical reactions. Clin Biochem 2004;37:112-9.

22. Erel O. A new automated colorimetric method for measuring total oxidant status. Clin Biochem 2005;38:1103-11. doi: 10.1016/j.clinbiochem.2005.08.008

23. Aykaç G, Uysal M, Yalçın AS, Koçak-Toker N, Sivas A, Öz $\mathrm{H}$. The effect of chronic ethanol ingestion on hepatic lipid peroxide, glutathione peroxidase and glutathione transferase in rat. Toxicology 1985:46:71-6.

24. Casini A, Ferrali M, Pompella AS, Maellaro E, Comporti M. Lipid peroxidation and cellular damage in extrahepatic tissues of bromobenzene intoxicated mice. Am J Pathol 1986: 123: 520-31.

25. Haklar G, Ulukaya-Durakbaşa C, Yüksel M, Dağlı T, Yalçın AS. Oxygen radicals and nitric oxide in rat mesenteric ischemia-reperfusion: modulation by l-arginine and $\mathrm{N}$-nitroL-arginine methyl ester. Clin Exp Pharmacol Physiol 1998;25:908-12.

26. Rodriguez JL, Miller CG, Garner WL, Till GO, Guerrero P, Moore NP, et al. Correlation of the local and systemic cytokine response with clinical outcome following thermal injury. J Trauma 1993;34:684-94.

27. Hansbrough JF, Wikstrom T, Braide M, Tenenhaus M, Rennekampff OH, Kiessig V, et al. Neutrophil activation and tissue neutrophil sequestration in a rat model of thermal injury. J Surg Res 1996;61:17-22. doi: 10.1006/jsre.1996.0074

28. Borovikova LV, Ivanova S, Zhang M, Yang H, Botchkina GI, Watkins LR, et al. Vagus nerve stimulation attenuates the systemic inflammatory response to endotoxin. Nature 2000;405:458-62.

29. Alexander JW, Boyce ST, Babcock GF, Gianotti L, Peck MD, Dunn DL, et al. The process of microbial translocation. Ann Surg 1990;212:496-510.

30. Dobke MK, Simoni J, Ninnemann TJ, Garrett J, Harnar TJ. Endotoxemia after burn injury: Effect of early excision on circulating endotoxin levels. J Burn Care Rehabil 1989;10:107-11.

31. Youn YK, Lalonde C, Demling R. The role of mediators in the response to thermal injury. World J Surg 1995;16:30-6.

32. Nieman GF, Zerler BR. A role for the anti-inflammatory 
properties of tetracyclines in the prevention of acute lung injury. Curr Med Chem 2001;8:317-25.

33. Zhu S, Stavrosvskaya IG, Drozda M, Kim BY, Ona V, Li M, et al. Minocycline inhibits cytochrome c release and delays progression of amyotrophic lateral sclerosis in mice. Nature 2002;41:74-8. doi: 10.1038/417074a

34. Ryan ME, Greenwald RA, Golub LM. Potential of tetracyclines to modify cartilage breakdown in osteoarthritis. Curr Opin Rheumatol 1996;8:238-47.

35. Cazalis J, Tanabe S, Gagnon G, Sorsa T, Grenier D. Tetracyclines amd chemically modified tetracycline-3 (CMT-3) modultae cytokine secretion by lipopolysaccharidestimulated whole blood. Inflammation 2009;32:130-7. doi: 10.1007/s10753-009-9111-9

36. Parenti A, Indorato B, Paccosi S. Minocycline affects human neutrophil respiratory burst and transendothelial migration. Inflamm Res 2017;66:107-9. doi: 10.1007/s00011-0160999-x

37. Kraus RL, Pasieczny R, Lariosa-Willingham K, Turner MS,
Jiang A, Trauger JW. Antioxidant properties of minocycline: neuroprotection in an oxidative stress assay and direct radical-scavenging activity. J Neurochem 2005;94: 819-27. doi: 10.1111/j.1471-4159.2005.03219.x

38. Pruzanski W, Greenwald RA, Street IO, La-leberte F, Stefanski E, Vadas P. Inhibition of enzymatic activity of phospholipase A2 by minocycline and doxycycline. Biochem Pharmacol 1992;44:1165-70.

39. Gabler WL, Tsukuda N. The influence of divalent cations and doxycycline on iodoacetamide-inhibitable leukocyte adherence. Res Commun Chem Pathol Pharmacol 1991;74: 131-40.

40. Thong YH, Ferrante A. Inhibition of mitogen-induced human lymphocyte proliferative responses by tetracycline analogues. Clin Exp Immunol 1979;35:443-6.

41. Davies GR, Simmond NJ, Stevens TRJ, Sheaf MT, Bnavala $\mathrm{N}$, Laurensen IF, et al. Helicobacter pylori stimulates antral mucosal reactive oxygen metabolite production in vivo. Gut 1994;35:179-85. 